\title{
Interpretasi Visual Sila Kedua dan Kelima Wayang Beber Pancasila
}

\author{
Sumbo Tinarbuko ${ }^{1}$, Cok Alit Artawan ${ }^{2}$ \\ ${ }^{1}$ Prodi Desain Komunikasi Visual, Fakultas Seni Rupa \\ dan Program Pascasarjana ISI Yogyakarta \\ ${ }^{2}$ Prodi Desain Komunikasi Visual, FSRD ISI Denpasar \\ ${ }^{1}$ sumbotinarbuko@gmail.com, 2alitartawan@isi-dps.ac.id
}

Penelitian ini disusun menggunakan metode penelitian kualitatif. Metode analisis semiotika komunikasi visual dimanfaatkan sebagai metode analisis tanda dan makna pada objek penelitian. Proses analisis dijalankan memakai konsep Triadik Sumbo Tinarbuko. Konsep ini penulis ciptakan untuk mendeskripsikan, menginterpretasikan dan menangkap makna konotasi yang terkandung pada sila kedua dan sila kelima Wayang Beber Pancasila. Penelitian ini dikerjakan dengan tujuan mengintrepretasikan secara visual makna konotasi sila kedua dan sila kelima Wayang Beber Pancasila. Hasilnya, pertama, pada sila kedua yang divisualkan lewat adegan Ratu Adil, menyampaikan pesan sosial diksi adil tidak dimaknai secara egois berdasar pendapat dan kesenangan diri pribadi. Diksi adil harus diselaraskan dengan tata nilai dan adat istiadat berdasarkan kondisi lingkungan sosial dan budaya yang ada. Kedua, pada sila kelima yang divisualkan dalam simbol Guyup Samudra, mengharapkan munculnya pengharapan baru berupa kesejahteraan sosial yang berkeadilan. Serta senantiasa menjunjung tinggi martabat dan kemuliaan sesama umat manusia.

Kata kunci: wayang beber pancasila, semiotika komunikasi visual, triadik sumbo tinarbuko.

\section{Visual Interpertation of the Second and Fifth Articles of Wayang Beber Pancasila}

This research is structured using qualitative research methods. The semiotic analysis method of visual communication is used as a method for analyzing signs and meanings of the research object. The analysis process was carried out using the Sumbo Tinarbuko Triadic concept. The author created this concept in order to describe, interpret and grasp the connotations contained in the second and fifth articles of Wayang Beber Pancasila. This research was conducted with the aim of visually interpreting the connotations of the second and fifth articles of Wayang Beber Pancasila. The result is in the second article, which is visualized by the Ratu Adil scene, that the conveyance of a social message of fair diction is not interpreted egotistically based on personal opinion and pleasure. Fair diction must be reconciled with values and customs based on the existing social and cultural conditions. Second, the fifth article of Wayang Beber Pancasila depicted in the symbol of Guyub Samudra hopes that new hopes will arise in the form of equitable social welfare and always preserve the dignity and honor of others.

Keywords: wayang beber pancasila, semiotics of visual communication, sumbo tinarbuko triadic. 


\section{PENDAHULUAN}

Wayang beber sejatinya gambar wayang yang dipertontonkan dengan cara diceritakan oleh sang dalang. Cerita lakon wayang beber diceritakan berdasarkan gambar yang dibeberkan di atas taferil wayang beber. Penjelasan rinci tentang wayang beber ditulis RM. Sayid (1980:14) Dewan Ahli Pedalangan Surakarta dalam bukunya berjudul: Bauwarna Kawruh Wayang, Sejarah Wayang Beber, '... Wayang beber punika wujud gambar ingkang ingkang kacorek wonten ing ndlacang. Gambar wau saben sajejeran utawi saadegan dipun singget mawi gambar wit-witan minangka kangge watwsing gambar ...'

Pada bagian lain bukunya, RM. Sayid (1980: 7) menuliskan risalah wayang beber sebagai gambar wayang purwa yang ditorehkan di atas lembaran kertas. Saat gambar wayang beber itu dipertontonkan harus digelar (jembreng/beber) dari gulungannya. 'Gambaring wayang purwa ingkang wonten ing dlancang lajeng dipun wastani wayang beber".

Perujudan visual wayang beber Pancasila secara nyata hadir dengan memparafrasekan keberadaan wayang beber. Ceritanya berisi gambaran visual dongeng pengamalan lima sila yang terkandung di dalam Pancasila. Representasinya dihadirkan di atas lembaran kertas atau kain kanvas. Saat dipergelarkan, gulungan panjang wayang beber Pancasila yang mencapai panjang berkisar 4-7 meter, dibeberkan di hadapan penonton yang menyaksikan tontonan pertunjukan wayang beber.

Wayang beber Pancasila dirancang dan dikreasikan oleh Indra Suroinggeno, seorang dalang wayang beber sekaligus si empunya Museum Wayang Beber Sekartaji, Yogyakarta. Hal itu dilakukannya dalam upaya membangun peradaban Pancasila bagi generasi milenial dan generasi ' $\mathrm{Z}$ ' di Indonesia.

Keberadaan wayang beber Pancasila selaras dengan pemikiran Bung Hatta, seperti dikutip Hariyono dalam makalahnya berjudul 'Pancasila Sebagai Spiritualitas Bangsa" (2019). Selengkapnya Bung Hatta menulis, "Bagi Republik Indonesia yang berdasarkan Pancasila, persamaan dan tidak membeda-bedakan status itu adalah pembawaan daripada ideologinya sendiri. Jika ditelaahkan benar-benar, tiap-tiap dari sendi negara yang lima itu memimpin dan menuntut realisasinya. Cita-cita kita semua ialah, bahwa warga negara Indonesia semuanya sama dalam status, dalam perasaan kemanusiaan dan perasaan kebangsaan, dalam hak dan kewajiban, dalam kebahagiaan dan kesejahteraan hidup".

Kehadiran wayang beber Pancasila diposisikan menjadi media komunikasi visual yang dapat memberikan solusi visual atas permasalahan sosial bangsa Indonesia seperti dituangkan di dalam Ketetapan MPR Nomor V/ MPR/2000, yakni nilai-nilai agama dan nilai-nilai budaya bangsa tidak dijadikan sumber etika dalam berbangsa dan bernegara. Hal kemudian melahirkan krisis akhlak dan moral yang berupa ketidakadilan, pelanggaran hukum dan pelanggaran hak asasi manusia.

Penelitian ini dikerjakan dengan menggunakan metode penelitian kualitatif. Sedangkan analisis objek penelitian memanfaatkan konsep analisis Triadik Sumbo Tinarbuko (Tinarbuko, 2017; Tinarbuko, 2020). Proses analisis objek penelitian diawali dengan mendeskripsikan, kemudian menginterpretasikan makna konotasi yang berasal dari tanda dan pesan yang ada di dalam taferil wayang beber Pancasila. Khususnya pada sila kedua Kemanusiaan yang Adil dan Beradab dan sila kelima Keadilan Sosial Bagi Seluruh Rakyat Indonesia.

Penelitian ini ditekankan pada proses interpretasi visual atas makna konotasi (Barthes, 2010), (Noth, 1995) yang muncul atas tanda serta pesan verbal dan pesan visual (Danesi, 2010), (Eco, 1979), (Judith, 1984) yang ada di taferil wayang beber Pancasila, khususnya penggambaran adegan sila kedua dan kelima. Hal lain yang difokuskan dalam penelitian ini, yakni menginterpretasikan makna konotasi pada proses interaksi desain komunikasi visual (Tinarbuko, 2015; Tinarbuko, 2017; Tinarbuko, 2020) yang ada di dalam taferil wayang beber Pancasila. Berdasarkan hal tersebut di atas, hasil penelitian ini menjadi bagian dari sumbangan teoretis bagi perkembangan karya desain komunikasi visual dalam ujud wayang beber Pancasila. Selain itu, hasil penelitian ini memaparkan singgungan teori tanda (semiotika) dengan ilmu desain komunikasi visual yang direpresentasikan di dalam wayang beber Pancasila. Terpenting, penelitian ini mamu memberikan angin segar dalam ujud interpretasi visual atas upaya pengamalan Pancasila dalam hidup dan kehidupan Generasi Milenial dan Generasi Z di Indonesia

\section{METODE PENELITIAN}

Penelitian ini disusun menggunakan metode penelitian kualitatif. Metode analisis semiotika komunikasi visual dimanfaatkan sebagai metode analisis tanda dan makna pada objek penelitian wayang beber Pancasila, khususnya sila kedua dan kelima. Penelitian ini dikerjakan dengan tujuan mengintrepretasikan secara visual makna konotasi sila kedua dan sila kelima Wayang Beber Pancasila

Metode analisis semiotika komunikasi visual pada tanda serta pesan verbal dan tanda visual sila kedua dan kelima wayang beber Pancasila, sejatinya beroperasi pada dua jenjang analisis. Pertama, analisis tanda secara individual, mencakup: tanda, kode, dan makna. Kedua, analisis tanda yang membentuk teks (Tinarbuko, 2020). Sedangkan teks menurut Yasraf Amir Piliang (1998:88) dipahami sebagai kombinasi tanda-tanda. Dengan demikian, dongeng adegan sila kedua dan kelima yang ada di dalam taferil wayang beber Pancasila dapat diposisikan sebagai sebuah 
teks.

Metode penelitian ini memanfaatkan metode analisis semiotika komunikasi visual dimanfaatkan sebagai metode analisis tanda dan makna pada objek penelitian wayang beber Pancasila, khususnya sila kedua dan kelima. Proses analisis dijalankan memakai konsep Triadik Sumbo Tinarbuko (Tinarbuko, 2017; Tinarbuko, 2020). Konsep ini penulis ciptakan untuk mendeskripsikan, menginterpretasikan dan menangkap makna konotasi yang terkandung pada tanda serta pesan verbal dan pesan visual yang terkandung di dalam sila kedua dan sila kelima wayang beber Pancasila.

Pada bangunan Triadik Sumbo Tinarbuko secara visual terpampang segitiga sama sisi. Bagian sisi sebelah kiri tampak titik Desain Komunikasi Visual (DKV) berada di bawah sendiri. Artinya, wayang beber Pancasila dipahami sebagai bagian dari karya DKV, karena di dalamnya mengandung pesan verbal dan pesan visual, serta dilengkapi dengan beberapa unsur elemen desain komunikasi visual. Antara lain berupa: garis, warna, ilustrasi, tipografi, bentuk dan komposisi.

Titik di atasnya berupa Konteks. Di dalam titik Konteks disepakati menjadi wilayah proses mengkaji karya wayang beber Pancasila, dalam bentuk identifikasi dan rumusan masalah).

Sedangkan titik paling atas berujud Teori. Di dalamnya berisi teori utama dan teori penunjang yang digunakan sebagai referensi untuk membantu mengkaji objek penelitian yang terdiri dari pesan verbal dan pesan visual sila kedua serta sila kelima wayang beber Pancasila.

Sedangkan bagian sisi sebelah kanan setelah titik Teori terdapat titik Konten. Di dalamnya berisi Bentuk Pesan (berujud karya desain komunikasi visual: garis, warna, ilustrasi, tipografi, komposisi) dan Isi Pesan (makna konotasi pesan verbal dan pesan visual) yang terkandung di dalam sila kedua dan sila kelima wayang beber Pancasila.

Titik paling bawah menjadi tempat Target Sasaran. Artinya, keberadaan pesan verbal dan pesan visual wayang beber Pancasila, diselaraskan dengan target khalayak sasaran yang dituju.Yakni Generasi Milenial dan Generasi Z di Indonesia.

Kemudian singgungan titik Target Sasaran dengan DKV ditempatkan titik Media. Artinya, wayang beber Pancasila membutuhkan media untuk merepresentasikan pesan verbal dan pesan visual yang ada di dalamnya. Untuk itu, dipilihlah media berupa gulungan taferil wayang beber.

Di atas titik Media menjulang diagonal ke kiri dan ke kanan membentuk segitiga sama sisi terbalik. Di sanalah ditempatkan alur berpikir analisis semiotika komunikasi

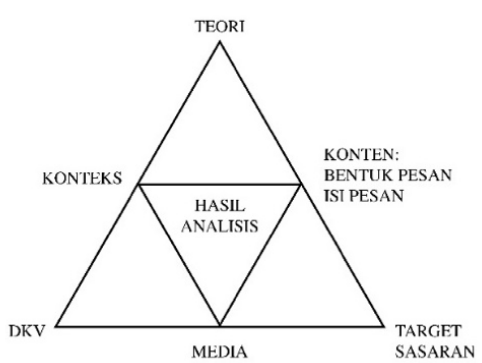

TRIADIK SUMBO TINARBUKO

visual berupa interpretasi visual atas makna konotasi sila kedua dan sila kelima hasil interpretasi visual wayang beber Pancasila (Tinarbuko, 2017; Tinarbuko, 2020)

\section{ANALISIS DAN INTERPRETASI DATA}

Wayang beber Pancasila hadir sebagai ujud varian baru dari perkembangan wayang beber. Hadirnya wayang beber Pancasila sebagai entitas baru atas parafrase visual wayang beber, sejatinya merupakan simbol penggambaran karakter manusia di dalam gerak semesta raya warga masyarakat di Indonesia. Keberadaannya dimunculkan sebagai simbol visual penyeimbang gerak zaman. Kehadirannya diposisikan menjadi representasi energi positif yang senantiasa dihembuskan dalam upaya membangun peradaban Pancasila bagi Generasi Milenial dan Generasi Z di Indonesia (Sayid, 1980; Tinarbuko, 2020).

\section{Pembahasan Sila Kedua Kemanusiaan yang Adil dan Beradab}

\section{Adegan Ratu Adil}

Adegan Ratu Adil ini membeberkan cerita visual berupa ikon papan permainan dakon yang terbuat dari kayu dengan hiasan ukiran floral. Di kedua ujung ikon dakon itu duduk bertimpuh seorang laki-laki telanjang dada dengan menggunakan kain sarung. Rambut sang lelaki itu digelung ke atas, biasa disebut dengan gelung Majapahitan. Sang lelaki menghadap ke kanan, menatap dengan takzim seorang perempuan yang duduk bertimpuh. Menurut Kamus Besar Bahasa Indonesia daring duduk bertimpuh diberi makna sebagai posisi duduk dengan kedua belah kaki terlipat dan ditindih oleh pantat.

Sementara itu, di sisi sebelah kiri, terlihat seorang perempuan duduk bertimpuh menatap sang lelaki dengan pandangan penuh takzim. Ikon perempuan di ujung dakon itu memakai jarik dan kemben sebagai busana rakyat kebanyakan. Rambutnya digelung ukel dihiasi dengan cunduk mentul dan bunga melati.

Di belakang mereka berdua, tampak digambarkan ikon tiga perempuan yang diletakan sejajar dengan ikon perempuan bergelung ukel. Ditilik dari busana dan rambut model diikat ke belakang, menjadi penanda visual, ketiga perempuan itu masih muda dan diberi tugas untuk menjadi 


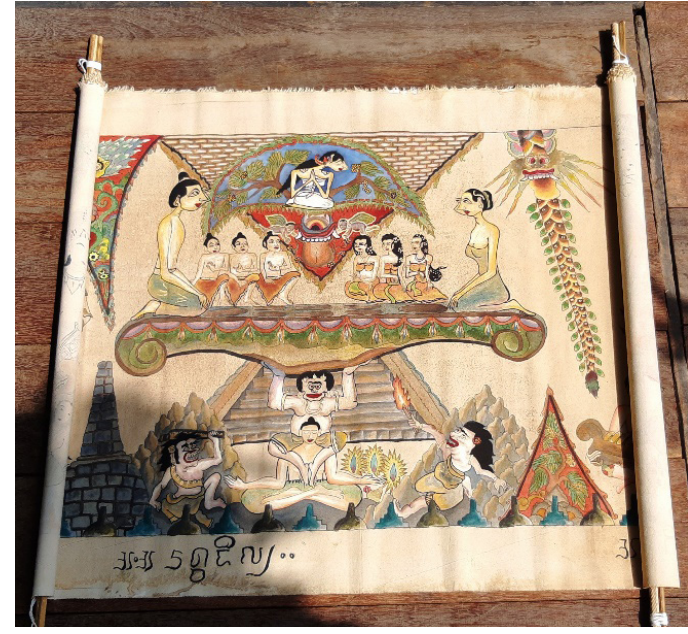

Gambar 1. Adegan Kedua: Ratu Adil (Sumber: Sumbo Tinarbuko, 2019)

penggembira sekaligus berperan sebagai penonton permainan dakon.

Di sebelah kanan ikon tiga perempuan juga tampak berjejer ikon tiga lelaki muda yang mengenakan sarung. Posisi duduknya setengah bersila. Melihat visualisasi ketiga ikon lelaki muda itu, patut diduga, mereka bertiga juga mendapat tugas yang sama seperti tugas yang diembat oleh ketiga ikon gadis belia di sisi kanan mereka.

Di atasnya tampak ikon seorang Ratu yang menghadap ke kanan, duduk di kursi singgasananya berbentuk segitiga sama sisi yang ujungnya menghadap ke bawah. Kedua tangan sang Ratu Adil ditangkupkan sedemikian rupa dan diletakan tepat di tengah dadanya. Keberadaannya menjadi simbol penengah di antara ikon lelaki dan perempuan yang duduk di sisi kiri dan kanan dakon.

Pada bagian bawah dari dakon tampak ikon seorang raksasa yang menyangga bagian tengah badan dakon. Ia menjaga posisi dakon lurus segaris dengan cakrawala. Sehingga dakon itu secara visual terjaga keseimbangannya. Tidak condong ke sebelah kiri atau pun tidak berat sebelah kanan. Di diri dan kanan ikon raksasa, hadir juga ikon dua raksasa yang juga ikut menjaga keseimbangan ikon dakon.

Pada bagian paling bawah, tampak terlihat ujung stupa yang dapat disaksikan di kompleks Candi Borobudur. Di sebelah kanan stupa Candi Borobudur hadir pula ikon stupa kecil berjumlah 13 stupa. Sedangkan di ujung atas dari tafril adegan Ratu Adil ini terlihat matahari yang menunjukan sinar kehangatan yang diancarkannya untuk menerangi dunia.

Adegan sang Ratu Adil ini memancarkan makna konotasi yang berlipat ganda. Dari gambaran taferil sila kedua wayang beber Pancasila ini, mengingatkan akan hadirnya tiga jenjang kehidupan seperti yang ada di candi Brobudur. Yakni tingkatan Kamadhatu, Rupadhatu dan Arupadhatu.

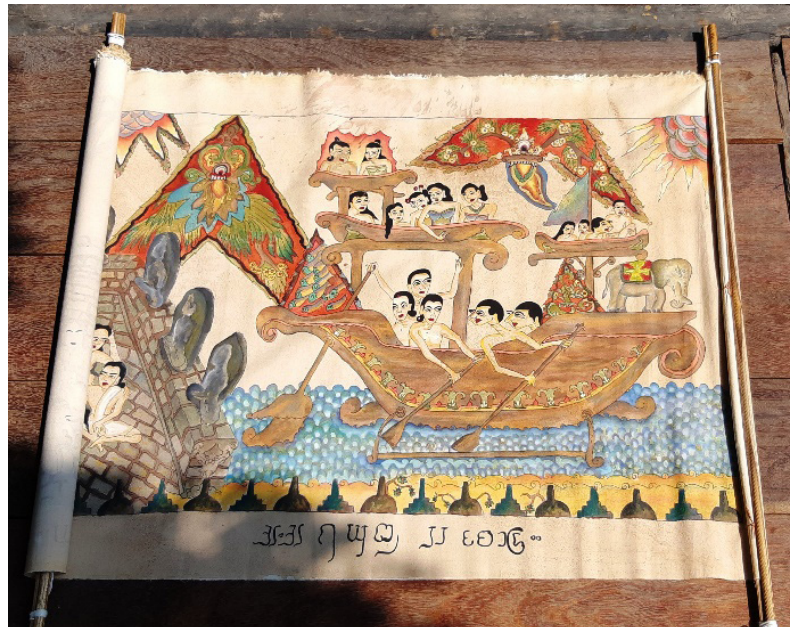

Gambar 2. Adegan Kelima: Guyub Samudra (Sumber: Sumbo Tinarbuko, 2019)

Ketiga jenjang kehidupan itu harus dijalankan oleh siapa pun.

Makna konotasi tahapan jenjang kehidupan semakin dikuatkan dengan hadirnya simbol timbangan dengan takaran beban yang seimbang antara bagian sebelah kiri dan kanan. Secara visual digambarkan dengan komposisi simetris. Membagi sama besar antara ruang di sebelah kanan dan kiri. Makna konotasi atas hadirnya simbol timbangan dapat dinterpretasikan sebagai bagian dari tugas dan kewajiban manusia untuk menjaga keseimbangan hidup dan kehidupan ini selagi masih disebut sebagai manusia.

Makna konotasi yang muncul dari pesan visual ini berupa representasi proses hidup dan kehidupan manusia dalam konteks patembayatan sosial. Sebuah upaya saling hormat menghormati saat menjalankan kehidupan sosial di ruang publik. Sebuah upaya menjalankan interaksi sosial sesama umat manusia dengan mengedepankan unsur kemanusiaan yang adil dan beradab. Selain itu juga berupaya menjaga keseimbangan hidup dan kehidupan dengan seluruh makhluk hidup yang ada di jagat raya ini.

Makna konotasi atas sila kedua Kemanusiaan yang Adil dan Beradab Adil yang ditorehkan di dalam taferil wayang beber Pancasila ini, menyampaikan pesan sosial bahwa diksi adil tidak dimaknai secara egois berdasar pendapat dan kesenangan diri pribadi. Tetapi diksi adil harus dimaknai dan diselaraskan dengan tata nilai dan adat istiadat setiap wilayah berdasarkan kondisi lingkungan sosial dan budaya yang sudah ada.

\section{Pembahasan Sila Kelima Keadilan Sosial Bagi Seluruh Rakyat Indonesia}

\section{Adegan Guyub Samudra}

Adegan ini membeberkan ikon kapal bahtera Nusantara yang mengarungi samudra kehidupan dunia. Setiap 
individu yang ada di kapal itu bersatu-padu demi menuju pelabuhan kebahagiaan yang mereka cita-citakan.

Makna konotasi yang muncul atas adegan Guyub Samudra ini menyampaikan pesan gotong-royong. Pemerintah, pejabat penyelenggara negara dan warga masyarakat wajib mengedepankan sikap guyup rukun demi mewujudkan kesejahteraan sosial bagi seluruh rakyat Indonesia.

Di dalam adegan kelima dibeberkan proses hidup dan kehidupan manusia yang sedang mengupayakan terwujudnya kesejahteraan sosial. Makna konotasi yang muncul atas adegan itu, untuk mewujudkan semuanya, dibutuhkan kebersamaan antara pemerintah, pejabat penyelenggara negara dan warga masyarakat dalam mendayung kapal kehidupan yang bermartabat dan manusiawi. Dengan kebersamaan, saling menghargai dan menghormati seperti yang digambarkan dalam pesan visual adegan kelima Guyub Samudra. Maka hasil yang diinginkan akan muncul pengharapan baru berupa kesejahteraan sosial yang berkeadilan. Serta senantiasa menjunjung tinggi martabat dan kemuliaan sesama umat manusia.

\section{SIMPULAN}

Penelitian ini dibuat untuk menginterpretasikan makna konotasi yang muncul atas interaksi tanda serta pesan verbal dan pesan visual pada wayang beber Pancasila. Secara khususnya penelitian ini mencoba menangkap makna konotasi wayang beber Pancasila yang terkandung pada sila kedua Kemanusiaan yang Adil dan Beradab serta sila kelima Keadilan Sosial Bagi Seluruh Rakyat Indonesia.

Makna konotasi yang muncul pada sila kedua dan sila kelima wayang beber Pancasila mengingatkan kepada seluruh rakyat Indonesia sejatinya hidup dan kehidupan di jagat raya ini sangat indah, nyaman dan aman.

Makna konotasi pada sila kedua menyampaikan pesan sosial diksi adil tidak dimaknai secara egois berdasar pendapat dan kesenangan diri pribadi. Diksi adil harus diselaraskan dengan tata nilai dan adat istiadat berdasarkan kondisi lingkungan sosial dan budaya yang ada.

Sedangkan makna konotasi pada sila kelima mendorong munculnya pengharapan baru berupa kesejahteraan sosial yang berkeadilan. Serta senantiasa menjunjung tinggi martabat dan kemuliaan sesama umat manusia. Hal itu menjadi sangat penting dijalankan oleh Generasi Milenial dan Generasi Z yang sekarang menjadi tulang punggung penggerak hidup dan kehidupan bangsa Indonesia.

\section{DAFTAR RUJUKAN}

Barthes, Roland (2010). Image/Music/Text atau Imaji Musik Teks, terjemahan Agustinus Hartono (1990). Penerbit Jalasutra, Yogyakarta.

Danesi, Marcel. (2010). Messages, Signs, and Meaning: A Basic Textbook in Semiotics and Communication Theory atau Pesan, Tanda, dan Makna: Buku Teks Dasar Mengenai Semiotika dan Teori Komunikasi, terjemahan Evi Setyarini dan Lusi Lian Piantari (2004). Penerbit Jalasutra, Yogyakarta.

Eco, Umberto. (1979). A Theory of Semiotics. Bloomington: Indiana University Press.

Hariyono. (15-16 Agustus 2019), “Aktualisasi Pancasila dalam Merajut Kembali Persatuan Bangsa". Makalah Kongres Pancasila XI, Universitas Gadjah Mada, di Yogyakarta.

Kasidi. (2019). Literatur Pedalangan: Balungan Lakon Wayang - Gagrag Ngayogyakarta Serial Harjunasasra - Ramayana - Sasana Hinggil Dwi Abad 2016-2017. Yogyakarta: Penerbit Dinas Kebudayaan (Kundha Kabudayan) Daerah Istimewa Yogyakarta.

Noth, Winfriend. (1995). Handbook of Semiotics. Blommington and Indianapolis: Indiana University Press.

Piliang, Yasraf Amir. (1998). Sebuah Dunia yang Dilipat, Realitas Kebudayaan Menjelang Milenium Ketiga dan Matinya Posmodernisme. Bandung: Penerbit Mizan.

Pimpinan MPR dan Badan Sosialisasi MPR RI. (2018). Materi Sosialisasi Empat Pilar MPR RI. Jakarta: Penerbit Sekretariat Jendral MPR RI

Sayid, R.M. (1980). Bauwarna Kawruh Wayang: Sejarah Wayang Beber. Solo: Penerbit Reksa Pustaka Pura Mangkunagaran.

Tinarbuko, Sumbo. (2017). Membaca Tanda dan Makna Desain Komunikasi Visual. Yogyakarta: Penerbit BP ISI Yogyakarta.

Tinarbuko, Sumbo. (2019). "'Membaca Makna Iklan Politik Pilpres 2019", dalam Mudra, Jurnal Seni dan Budaya, Volume 32 No. 2, Pusat Penerbitan LP2MPP ISI Denpasar.

Tinarbuko, Sumbo. (2020). Perancangan dan Pengkajian Desain Komunikasi Visual. Yogyakarta: Penerbit BP ISI Yogyakarta. 
Williamson, Judith. (1984). Decoding Advertisements, Ideology and Meaning in Advertising. London: Marion Boyars Publishers Ltd, 24 Lacy Road.

Webtografi

https://kbbi.web.id/timpuh 